\title{
EÖTVÖS LORÁND-EMLÉKÉV 2019
}

2019-ben nem csak Magyarországon emlékeztünk Eötvös Lorándra halálának századik évfordulója alkalmából. Ez a centenárium is ott volt azon a történelmi események és neves személyiségek évfordulóit tartalmazó listán, amelyekről való megemlékezéshez az UNESCO is csatlakozott, hogy mutassa: ezek az egész emberiség számára jelentőséggel bírnak.

Az elmúlt év folyamán - döntően fizikusok és geofizikusok szervezésében, az MTA és az Eötvös Loránd Tudományegyetem erkölcsi, a Nemzeti Kutatási, Fejlesztési és Innovációs Hivatal anyagi támogatásával, a Szarka László akadémikus által vezetett Eötvös 100 testület koordinálásával - egy sor ünnepi esemény került megrendezésre, elsősorban Magyarországon, de Erdélyben, a Felvidéken és a Délvidéken is voltak megemlékezések, sőt a Nyugat-Európában és Amerikában rendezett nemzetközi konferenciákon is lehetőség nyílt Eötvös Loránd életmüvének bemutatására legalább egy-egy poszterkiállítás segítségével. Külön említést érdemel a középiskolásokat is megmozgató emlékverseny. Ezeknek az eseményeknek a listája, az ott elhangzott előadások megtalálhatók a www.eotvos100.hu honlapon. A megemlékezések maradandó lenyomataként két könyv jelent meg. Ezek bemutatására tavaly novemberben az MTA székházában a Magyar Tudomány Ünnepéhez, illetve a World Science Forumhoz kapcsolódva került sor.

Az első, a Patkós András és Gyáni Gábor föszerkesztők, valamint Dobszay Tamás és Estók János szerkesztők nevével fémjelzett Eötvös Loránd emlékalbum, amely közel nyolcvan színes képpel gazdagon illusztrálva, népszerúen megírva, széles olvasóközönséget megcélozva mutatja be Eötvös Loránd életét, munkásságát, hatását. A munka mintegy fele-fele arányban foglalkozik Eötvössel mint tudóssal, ,,a klasszikus fizika egyik fejedelmével”, ahogyan állítólag Albert Einstein nevezte halálhírének hallatán, a geofizika egyik atyjával, illetve Eötvös közéleti, tudományszervezői és egyéb tevékenységével. Hangsúlyos az egyéb szó, hiszen Eötvös Loránd nemcsak egyetemi rektor, akadémiai elnök és kultuszminiszter volt élete egy-egy szakaszában, hanem aktív sportember, hegymászó, aki évtizedeken keresztül nyaranta - sokszor leányaival együtt - rendszeresen túrázott a dél-tiroli Dolomitokban, néhány csúcsot pedig elsőként hódított meg. A könyvet Eötvös Loránd élete legfontosabb eseményeinek kronologikus bemutatása, és a róla írt cikkek bibliográfiája egészíti ki.

Különös érdekessége ennek a könyvnek, hogy a magyar szerzők mellett Ephraim Fischbachtól, a Purdue University professzorától is tartalmaz egy írást, amelyben Eötvös leghíresebb mérésének, a tehetetlen és súlyos tömeg arányos- 
ságát rendkívüli pontossággal alátámasztó kísérletnek máig tartó hatását elemzi a szerző.

Ezen a ponton érintkezik ez a munka a másik, Kilényi Éva által szerkesztett kötettel, melynek címe Az Eötvös kísérlet - történelmi keretben. Ez a könyv kimondottan a terület szakértőinek készült, ugyanakkor rendkívül fontos tudománytörténeti dokumentum.

A már említett téma, a tehetetlen és súlyos tömeg arányossága már az 1880-as évek második felében foglalkoztatta Eötvöst. Ekkor végezte az első ilyen méréseit. Még intenzívebben folytatta ezeket, amikor 1906-ban a Göttingeni Királyi Tudományos Társaság Beneke alapítványa pályadíjat írt ki a tehetetlenség és a tömegvonzás arányosságára vonatkozó newtoni törvény eddigieknél nagyobb pontosságú vizsgálatára. A pályadijat 1909-ben az Eötvös és két munkatársa, Fekete Jenő és Pekár Dezső által benyújtott mủ nyerte el.

A benyújtott munka nem maradt ránk. Az elért eredményekről csak Eötvös halála után, 1922-ben jelent meg a híres Eötvös-Pekár-Fekete-cikk, amelyben jelezték, hogy az eredeti tanulmány terjedelme miatt szükségessé vált az értekezés nagymértékủ rövidítése. Mivel Eötvös hagyatékát az Eötvös Loránd Geofizikai Intézet (ELGI) örizte, vélhető volt, hogy ott vannak az eredeti kéziratok. A kétezres évek elején az ELGI-ben - az intézmény költözése során történt keveredés miatt nem pontosan a várt helyen - valóban elökerült az az Eötvös által a pályamunkához tartozó mérések idején készített kézirat, amelyben a mérési eredményeket elemzi. Ez annyira felkeltette a már említett Fischbach érdeklődését, hogy rávette a Brookhavenben dolgozó Dávid Gábort a német nyelvủ kéziratnak nyomtatható változatba történő átültetésére. Dávid Gábor pedig annyira beleszeretett ebbe a munkába, hogy ennél jóval többet tett. Gondosan összevetette az 1906 és 1909 között Eötvös által írt kéziratot a két munkatárs által 1922-ben hármuk nevében megjelentetett cikkel, megkeresve, hogy hol melyik tartalmaz többet.

A könyv igazi érdekességét éppen az adja, hogy a kézirat facsimiléje mellett ott találjuk a Beneke-pályázatra készült anyagnak egy így rekonstruált változatát, amely a kézirat és az Eötvös-Pekár-Fekete-cikk egyesítése révén jöhetett létre. Pontosan követhető, hogy mely részek maradtak ki a cikkből vélhetően terjedelmi okokból, és ezért most látnak elöször napvilágot, és melyek azok a részek, amelyek a munkafolyamat közben készült kéziratba még nem kerültek be.

Ebben a formában a mủ nemcsak tudománytörténeti érdekességű, hanem az ezzel foglalkozók számára fontos információk forrása. Ezért a magyar kiadás mellett a könyv angol nyelven is megjelent. Ugyanez vonatkozik egyébként az emlékalbumra is. Annak is született egy angol változata, hogy segítségével még szélesebb körben lehessen ismertté tenni Eötvös Loránd emberi nagyságát, fantasztikus életmüvét, tudományos tevékenységének máig tartó hatását. A szélesebb megismerhetőséget segíti az, hogy mindkét könyv magyarul és angolul 
is hozzáférhető az MTA KIK által kezelt REAL repozitóriumban (az ún. Beneke-kötet angolul csak kérésre, a többi könyv szabadon). Az online kiadásnak az az elönye is megvan, hogy a fájlok konverziója során a Beneke-kötet nyomtatott változatába becsúszott nyomdahibákat már javították.

(Dobszay Tamás-Estók János-Gyáni Gábor-Patkós András szerkesztök: Eötvös Loránd emlékalbum. Budapest: Kossuth Kiadó, 2019, 175 o. http://real-eod.mtak. hu/8253/

Tamás Dobszay-János Estók-Gábor Gyáni-András Patkós editors: Roland Eötvös Memorial Album. Budapest: Kossuth Publishing, 2019, 175 p. http://real-eod. mtak.hu/3799/

Kilényi Éva szerkesztő: Az Eötvös kísérlet - történelmi keretben. Budapest: Unicus Mühely, 2019, 232 o. http://real-eod.mtak.hu/8265/

Éva Kilényi editor: The Eötvös Experiment in Its Historical Context. Budapest: Unicus Mühely, 2019, 232 p. http://real-eod.mtak.hu/8266/)

Sólyom Jenő az MTA rendes tagja 